TITLE:

\title{
A PRELIMINARY LIST OF THE PELAGIC CEPHALOPODA FROM THE JAPAN SEA
}

$\operatorname{AUTHOR(S):~}$

Nishimura, Saburo

\section{CITATION:}

Nishimura, Saburo. A PRELIMINARY LIST OF THE PELAGIC CEPHALOPODA FROM THE JAPAN SEA. PUBLICATIONS OF THE SETO MARINE BIOLOGICAL LABORATORY 1968, 16(1): 71-83

ISSUE DATE:

1968-06-29

URL:

http://hdl.handle.net/2433/175487

RIGHT: 


\title{
A PRELIMINARY LIST OF THE PELAGIC CEPHALOPODA FROM THE JAPAN SEA ${ }^{13}$
}

\author{
SABURO NISHIMURA
}

Seto Marine Biological Laboratory, Sirahama

The pelagic Cephalopoda is defined here to include the oegopsidean families of the order Decembrachiata (=Decapoda) and all the families of the order Octopodida with the exception of the primarily benthonic Octopodidae. These cephalopods are caught or observed only rarely or merely by chance, e.g., from the stomach of predatory fishes or being stranded ashore, except for a few species which are caught in quantities by commercial fisheries. Consequently, their specimens are usually rather rare and their records are widely scattered in literature. This is not exceptional for the fauna in the Japan Sea, either. It seems thus pertinent to compile such records and data in order to list up here preliminarily the pelagic cephalopod fauna of this marginal sea as far as possible. The geographical area covered by this study is the Japan Sea inclusive of the strait areas of Tsushima, Tsugaru, Sôya (La Pérouse) and Mamiya (Tartary). Mutsu Bay at the northern end of Honshu Island is also included, since the hydrography and the animal communities of the bay show a much closer affinity to those in the Japan Sea proper than to those in the Pacific area just east of the Tsugaru Straits. Common Japanese names are shown whenever they are available, and the localities and the sources of records are given as far as possible for each species in a hope to help further studies by local naturalists. New localities are marked by the sign (!). Short biological notes are given for certain remarkable species. Moreover, the localities of findings of empty shells of the tetrabranchiate Nautilus are listed additionally.

Acknowledgments__ I am indebted to Dr. A. Ochial of the Department of Fisheries, Kyoto University, Maizuru (now at the Institute of Cultural Fisheries, Kôchi University), to Messrs. R. Mizusawa at Nô, Niigata Prefecture, and C. Sugthara at Sakata, Yamagata Prefecture, for their kind informations. My thanks are also due to Mr. M. Oriyama of the Japan Sea Regional Fisheries Research Laboratory, Niigata, for his kind help in various ways. The manuscript was read by Dr. T. TokiokA of our laboratory, to whom I am most grateful.

1) Contributions from the Seto Marine Biological Laboratory, No. 488 .

Publ. Seto Mar. Biol. Lab., XVI (1), 71-83, 1968. $\quad$ (Article 9) 


\section{Class CEPHALOPODA \\ Order DECEMBRACHIATA \\ Suborder TEUTHOIDEA \\ Superfamily Oegopsida \\ Family Enoploteuthidae}

Enoploteuthis chunii C. Ishrkawa, 1914 Japanese name: Hotaruika-modoki

Toyama Bay (C. Ishikawa 1914; Matsuno 1914; Sasaki 1916; Ichijima 1927);

Izumozaki, Niigata Pref. (Nakamura 1925); off Noto Peninsula (Tokuhisa 1915 ) ; off Unkovsky Bay, southeast Korea (Yamada 1937); $38^{\circ} 27^{\prime} \mathrm{N}, 1^{\circ} 7^{\circ} 09^{\prime} \mathrm{E}$, in the stomach of the whiting Theragra chalcogramma (Shimomura \& Fukataki 1957, p. 274; Tabata 1958); off Tsuiyama, Hyôgo Pref., in stomachs of various predatory fishes (WATANABE et al. 1958).

Enoploteuthis theragrae TAKI, 1964 J.n.: Taraba-hotaruika-modoki

Off the prefectures of Hyôgo and Fukui, in the stomah of the whiting in both cases (TAKI 1964); Ryôtsu Bay, Sado Island, in the stomach of the dealfish Trachipterus ishikawai (Nishimura 1964).

This species seems very common in moderate depths of the Japan Sea, since it is found frequently in the stomach of the whiting taken from various places (!). Allied very closely to the preceding species.

Abralia japonica M. Ishikawa, 1929

Toyama Bay (M. Ishikawa 1929).

Nakamura (1925, p. 413) refers under the Japanese name 'hotaruika-modoki' to an enoploteuthid which lacks photophores on the tip of the IV arms. Is this enoploteuthid identical with the present species? No mention as to its exact locality.

Abralia sp.

? Namerikawa, Toyama Pref. (Taki \& Igarashi 1967, p. 14: an intermediate form between Abralia andamanica Goodrich and $A$. multihamata SASAKI).

Watasenia scintillans (Berry, 1911) J.n.: Hotaruika

Toyama Bay (Watasé 1905; Berry 1911; C. Ishikawa 1913b; Sasaki 1914, 1916; Ínijima 1927; Taki \& Igarashi 1967); Noto Peninsula (Tokuhisa 1915); east of Noto Peninsula, 527-548 fms (SASAkI 1920); Wagi, Sado Island (TAKI \& Igarashi 1967); Nishikubiki, Niigata Pref. (Nakamura 1925); Nishitagawagun, Yamagata Pref. (TAKI \& Igarashi 1967); off Tsuiyama, Hyôgo Pref., in stomachs of various predatory fishes (WATANABE et al. 1958); near Cape Clonard, Korea, 70-150 fms (Sasaki 1920); 60 miles east of Change Point, southeast Korea, 
in the stomach of the chub mackerel Scomber japonicus (Yamada 1937); 45 miles SSE of Ullong Island, in the stomach of the chub mackerel (Yamada 1937); off Chumunjin, east Korea, in the stomach of the whiting (Yamada 1937).

This squid seems very common in the Japan Sea. Abundantly caught in Toyama Bay by set net (SASAkI 1914; Matsuno 1921). It is also frequently found ingested in stomachs of various predatory fishes; however, records of this species in the fish stomach analysis made prior to 1955 by Japanese fisheries biologists may often include some different enoploteuthids else. Pelagic squid eggs commonly found in the surface layer throughout the Japan Sea but mainly off eastern Korea and west Honshu were supposed by Yamada (1937), Yamamoto (1942), Shimomura \& Fukataki (1957) to belong to this species; this identification is, however, not yet confirmed definitely.

Abraliopsis morrisi (VÉRANY, 1837)

Central Japan Sea (Aкimushkin 1963, fig. 48).

Very probably Akimushkin's record was based on young specimens of Watasenia scintillans.

Family Gonatidae

Gonatus magister BERRY, 1913

J.n.: Dosuika

Off Iwanai, Hokkaido, 428 fms (SASAKI 1920); Sado Straits (OkiYama 1965); Nishikubiki, Niigata Pref. (Nakamura 1925); Toyama Bay (SAsakr 1916; Ichijima 1927); off Noto Peninsula (Tokuhisa 1915); around Oki Islands, 330 m (Hamabe 1965, p. 123); near Cape Clonard, southeast Korea, 400 fms (SAsAKI 1920); off southern Maritime Province (Kondakov 1941; Akrmushkin 1963, fig. 53).

Cold-bathypelagic species. Окгуама (1965) considers that this is common in the Japan Sea.

Gonalus fabricii (Lichtenstein, 1818)

J.n.: Tekagiika

Peter the Great Bay (Kondakov 1941; Akimushkin 1963, fig. 50).

Gonatopsis borealis SASAKI, 1923

J.n.: Takoika

Around Hokkaido (Yamaguchi \& Yamada 1955); northern Japan Sea, expedition sample (!).

Tokurrsa (1915) refers to a kind of squid which is called 'takoika' and said to be found in the deep waters of Toyama Bay. This might be G. borealis.

Family Onychoteuthidae

Onychoteuthis banksi (LEACH, 1817)

J.n.: Tsuméika

Oriyama (1965) lists this species as a member occurring in the Japan Sea. This 
is based on a specimen from the stomach of a salmon shark Lamna ditropis caught off the west coast of northern Sakhalin in the spring of 1963 and identified by $\mathrm{H}$. Fukataki of the Japan Sea Regional Fisheries Research Laboratory. Nakamura (1925) records ? O. banksi from Izumozaki, Niigata Prefecture.

Moroteuthis robusta (VERRILL, 1876) J.n.: Nyûdôika

South of the Tsugaru Straits (IsHrkaWA \& Wakrya 1914).

The exact locality of this record is uncertain; however, IsHIKAWA \& WAKIYA's statement that it was found in the stomach of a sperm whale Physeter catodon suggests that it came not from the Japan Sea but from somewhere else in the Pacific south of the east entrance to the Tsugaru Straits, viz. off Sanriku District of northeastern Honshu, because the sperm whale usually migrates off Sanriku District but never enters the Japan Sea through the Tsugaru Straits.

\section{Family Ommastrephidae}

Ommastrephes bartrami (Lesueur, 1812)

J.n.: Bakaika

Tsugaru Straits (SAsAki 1929a; TAKi 1965; !); Toyama Bay (Ichijima 1927); around the Yamato Bank, central Japan Sea (TAKI 1965); Oki Islands (HAMABE 1962); Ôi coast, Abu-gun, Yamaguchi Pref. (Tanaka 1950).

Todarodes pacificus (Steenstrup, 1880)

J.n.: Suruméika

Hakodate (STeenstrup 1880; Berry 1912; Sasaki 1916, 1920; Taki \& Igarashi 1967); Takashima, Hokkaido (SASaki 1916; Taki \& Igarashi 1967); Oshoro, Hokkaido (Sasaki 1916; Taki \& Igarashi 1967); Shioya, Hokkaido (Taki \& IgARASHI 1967); off Shakotan, Hokkaido (SASAKI 1916); off Ohana-misaki, Hokkaido (Sasaki 1916); Obuyu-saki, Hokkaido (SaSaki 1916); Todohokke, Hokkaido (Wülker 1910); Tsugaru Straits (TAKI \& Igarashi 1967); Asamushi, Mutsu Bay (Sasaki 1929a); Shônai Prov., Yamagata Pref. (Suzuki 1963); Niigata (G. Ishikawa 1913a); Ryôtsu, Sado Island (Sasaki 1920); Toyama Bay (C. Ishikawa 1913a; Sasaki 1916; Ichijima 1927; Taki \& Igarashi 1967); Usetsu, Noto Peninsula (Sasaki 1916); Oki Islands (Sasaki 1920, 1921, 1929b; Hamabe 1965); Iwami Prov,, west Honshu (C. Ishikawa 1913a); central Japan Sea (Iтo et al. 1965); Tsushima Islands (Yamamoto 1946; Tanaka \& IrzUKa 1965); off Cape Clonard, Korea, $70 \mathrm{fms}$ (SASAKI 1920); east and southeast Korea (Yamamoto 1942, 1946); around Utsuryô-tô Island (Yамамото 1942, 1946); Peter the Great Bay (Joubin 1879; Kondakov 1941; Kondakov in Slepzov 1955; Akimushrin 1963); Maritime Province (Kondakov 1941; Akimushkin 1963); Tartary Straits (Kondakov 1941; Akimushkin 1963).

Very abundant in both the coastal and offshore waters; primarily in the epipelagic layers. An extensive seasonal migration is known. 


\section{Family Architeuthidae}

Architeuthis sp.

J.n.: Daiôika

Arahama, Kashiwazaki-shi, Niigata Pref., Feb. 6, 1960, stranded; mantle length $1.3 \mathrm{~m}$, total length $3.5 \mathrm{~m}$, weight $112 \mathrm{~kg}$ (Nishimura 1960b); Ashiya, Hamasaka-machi, Hyôgo Pref., Feb. 4, 1958, stranded; total length $4.1 \mathrm{~m}$, weight ca. 150 kg (Kamita 1962); Ôi, Hirata-shi, Shimane Pref., Jan. 23, 1961, stranded; total length $2.6 \mathrm{~m}$, weight $41.2 \mathrm{~kg}$ (Kamita 1962); Susa Bay, Yamaguchi Pref., February 1941; mantle length ca. $1.5 \mathrm{~m}$, weight ca. $180 \mathrm{~kg}$ (Tanaka 1950); off Hagi, Yamaguchi Pref., Feb. 7, 1958; total length ca. $6 \mathrm{~m}$, weight $170 \mathrm{~kg}$ (КАMita 1962).

Unidentified giant squids were caught at the following localities in the Oki Islands (Hamabe 1957); very likely they were Architeuthis sp.: off Kuniga, in the beginning of the Shôwa Era [1926], in early spring; Uragô Bay, some time before the preceding record; Misaki, Dec. 14, 1957.

Specific identification of the specimens mentioned above were impossible, but all might be Architeuthis japonica Pfeffer, 1912. It is seen from the abovegiven records that the occurrences which were recognized mostly by stranding are concentrated in winter to early spring and more densely on the coast of San'in District, west Honshu, than in more northerly districts. Such a trend may suggest that Architeuthis is originally an inhabitant of the warm waters in the Pacific, carried into the Japan Sea through the Tsushima Straits by warm ocean currents in summer to autumn and then affected by the marked cooling of the water starting in late autumn in this marginal sea to be paralysed, brought by the drift currents toward the shore, especially in the western half of Honshu Island, and eventually washed ashore. The population of this species in the Japan Sea may be allogenetic, as supposed already by S. IwATA in Kamita (1962).

\section{Family Thysanoteuthidae}

Thysanoteuthis rhombus TROschel, 1857

J.n.: Sodéika

Yoichi, Hokkaido (Kinoshita 1939); Wakimoto, Hokkaido, facing the Tsugaru Straits (Taki \& Igarashi 1967); off Ôhata, Aomori Pref. (I. OKaghi in Nishimura 1966); Aomori Bay, Nov. 9, 1966 (!); Horotsuki, Aomori Pref. (M. Tanabe in Nishimura 1966); Fukuma, Aomori Pref. (M. Tanabe in Nishimura 1966); Akita Pref. (M. Oriyama in Nishimura 1966); Atsumi, Yamagata Pref. (!); Nezugaseki, Yamagata Pref. (!); Iwafune-gun, Niigata Pref. (Nishimura 1966); Niigata (Nishimura 1966); Maki-machi, Niigata Pref. (Nishimura 1960a); Teradomari, Niigata Pref. (Nishimura 1966); Naoetsu, Niigata Pref. (Nishimura 1960a); Itoigawa, Niigata Pref. (Nishimura 1966); Washizaki, Sado Island (Nishimura 1960a); Ryôtsu, Sado Island (Nishimura 1966); Kanaizumi, Sado 
Island (Iwasawa 1962); Etchû Prov. [Toyama Pref.] (Sasaki 1916); Toyama Bay (Toyama Pref. Fish. Exp. Stat. 1965; Y. Morita in Nishimura 1966); Noto Peninsula (Tokuhisa 1915; Sasakr 1916); Usetsu, Noto Penin. (Nishimura 1966); Echizen-machi, Fukui Pref. (Samon 1964; I. OKachi in Nishimura 1966); Tsuruga (Fukui Pref. Fish. Exp. Stat. in Nishimura 1966); Tango Prov. [Kyoto Pref.] (Sasaki 1916); Maizuru, Kyoto Pref. (Nishimura 1966); Kasumi, Hyôgo Pref. (Tsutsui et al. 1963); Karo, Tottori Pref. (Nishimura 1966) ; Saigô, Oki Islands (Kamita 1962); Uragô, Oki Islands (Hamabe 1962; S. Iwata in Kamita 1962; Y. Kimura in Kamita 1965); Tsuma, Oki Islands (Y. Kimura in Kamita 1965); Shimane-mura, Shimane Pref. (Kamita 1962); Koryô-mura, Shimane Pref. (Nishimura 1966); Shizuma-machi, Shimane Pref. (Kamita 1962); Hamada, Shimane Pref. (S. Inata in Kamita 1962; K. Nakano in Nishimura 1966); Masuda, Shimane Pref. (Kamita 1962; K. Nakano in Nishimura 1966); Takayama, Yamaguchi Pref. (K. Nakano in Nishimura 1966); Hagi, Yamaguchi Pref. (K. Nakano in Nishimura 1966); Tsuyazaki, Fukuoka Pref. (S. Mito in Nishimura 1966); Shingû-hama near Fukuoka (Tabeta \& Tsukahara 1967); Fukuma-machi, Fukuoka Pref. (Nishimura 1966); Iki Island, northwest Kyushu (S. Mito in Nishimura 1966); 'Tsushima Islands (Sasaki 1929a); Pusan, Korea (M. Ishikawa 1933; Yamamoto 1942).

This is a migrant into the Japan Sea, being driven by warm ocean currents (Nishimura 1966).

\section{Family Chiroteuthidae}

Chiroteuthis imperator GHun, 1910

J.n.: Yûreiika

Nakamura (1925, p. 413) records ?C. imperator from Shimojuku, Niigata

Prefecture.

This interesting record remains, however, unverified.

Family Cranchiidac

Cranchia scabra LEACH, 1817

J.n.: Saméhada-hôzukiika

Nô, Niigata Pref. (Mizusawa 1964).

Crystalloteuthis behringiana SASAKI, 1920

Near the Sôya (La Pérouse) Straits (SASAKI 1920).

\section{Order OCTOPODIDA}

Suborder INGIRRATA

Superfamily Ctenoglossa

Family Amphitretidae 
Amphitretus pelagicus Hoyle, 1885

Japanese name: Kuragédako

Maizuru, late April, 1965, by set net (A. OaHiaI, personal information, Sept. 18, 1967).

Superfamily Argonautida

Family Alloposidae

Alloposus mollis VERRILL, 1880

J.n.: Kantendako

Off Nô, Niigata Prefecture, Mar. i5, 1967, by trawl (Mrzusawa 1967).

A large 'gelatinous' octopod trawled off Atsumi, Yamagata Pref., on Oct. 13,1957 , and reported in a local newspaper as a sea-bottom monster may belong to this species; it weighed about $20 \mathrm{~kg}$.

\section{Family Tremoctopodidae}

Tremoctopus violaceus Delle Cihiaje, 1830

J.n.: Murasakidako

Furubira, Hokkaido, Sept. 10, 1964 (UEno 1964); Yoichi, Hokkaido, Sept. 19, 1964 (Ueno 1964); off Kinobe, Aomori Pref., Dec. 6, 1961 (!); Tobishima Island, Yamagata Pref. (C. SugitharA, personal information, Sept. 13, 1967); Yura coast, Tsuruoka, Yamagata Pref., Sept. 2, 1967, by angling (!); Niigata, Aug. 27, 1961 (Nishimura 1961); Ryôtsu, Sado Island, Aug. 30, 1961 (Nishimura 1961); Kanaizumi, Sado Island (Iwasawa 1962); Namerikawa, Toyama Pref., Oct. 29, 1956 (Nishrmura 1961); Ishikawa Pref. (? Usetsu), Nov. 12, 1958 (Ishikawa Pref. Fish. Exp. Stat. 1958); Matsunami, Ishikawa Pref., Oct. 7, 1958 (!); Tsuruga, Sept. 12, 1964 (!); Tango Prov. [Kyoto Pref.] (Sasaki 1929a); Kasumi, Hyôgo Pref., Jul. 17, 1949 (Yamamoro 1951); Mihogaseki, Shimane Pref., Sept. 13, 1957 and winter, 1959 (Kamrta 1962); Hagi, Yamaguchi Pref. (TAnaka 1950); Shingû-hama near Fukuoka, rather frequently (Tabeta \& Tsukahara 1967); Pusan, Korea (Yamamoto 1942).

Evidently, most of the occurrences are recorded in late summer to early winter, but slightly delayed with the latitude. This suggests that Tremoctopus enters the Japan Sea at the peak of the warm ocean currents and follows mainly the course along the coastal branch of the Tsushima current keeping close to the west coast of Honshu up to the west coast of Hokkaido.

Family Ocythoidae

Ocythoe tuberculata RAFINEsQUE, 1814 J.n.: Amidako

? Hakodate (SAsaki 1929a); Ryôtsu Bay, Sado Island, June 25, 1962, by set net (R. Mizusawa, personal information, Feb. 22, 1963); Kanaizumi, Sado Island (Iwasawa 1962); off Hagi, Yamaguchi Pref., Oct. 7, 1936 (Tanaka 1950). 
Family Argonautidae

Argonauta argo Linnaeus, 1758

J.n.: Aoigai

Yoichi, Hokkaido (Kinoshita 1939; НаSнimoto 1965); Iwanai, Hokkaido (SASAKI 1929a); Oshoro, Hokkaido (TAKI \& Igarashi 1967); Hakodate (TAKI \& Igarashi 1967); off Ôhata, Amomori Pref. (Nishimura 1968); Noheji, Aomori Pref. (Toba 1935); Aomori Bay (Sasaki 1929a); west coast of Aomori Pref. ("Saikai Zokudan" 1758"); TANABE \& UKawA 1958); Nezugaseki, Yamagata Pref. (Suzuki 1963); Jûrizuka near Sakata, Yamagata Pref. (Suzuki 1963); Tobishima Island (Suzuki 1963); Sado and Echigo Provinces [Niigata Pref.] ("Tanki Manroku" 18323)); Iwafune-gun, Niigata Pref. (Nishimura 1962); Niigata (Nishimura 1962); Kashiwazaki, Niigata Pref. (Nakamura 1925); Ryôtsu, Sado Island (Iwasawa 1962; Ikehara 1965); Kanaizumi, Sado Island (Iwasawa 1962); Toyama Bay (Iсhijima 1927; Sasaki 1929a; Kikuchi 1931; Nishimura 1962); off Noto Peninsula (38 $33^{\prime} \mathrm{N}, 135^{\circ} 40^{\prime} \mathrm{E}$ ) (H. Fukataki in Nishrmura 1968); Awagasaki, Kaga Prov. [Ishikawa Pref.] (Kubota 1962); Ayukawa, Fukui Pref. (Fukui Municipal Mus. in Nishimura 1968); Niyû, Tsuruga, Oniyû and Ôi, all in Fukui Pref. (Kuroda 1933); Takahama, Fukui Pref. (T. Kuroda in Kobayashi 1954; Kubota 1962); Tango Prov. [Kyoto Pref.] (Hirase 1907; Yagura 1932); Tajima Prov. [Hyôgo Pref.] (Yagura 1932; Ito 1967); Kokufu-machi, Shimane Pref. (Kamita 1938, 1962); Masuda, Shimane Pref. (K. Nakano in Nishimura 1967); Oki Islands (Kamita 1965); off Oki Islands $\left(37^{\circ} 17^{\prime} \mathrm{N}, 133^{\circ} 36^{\prime} \mathrm{E}\right.$ ) (H. Fukataki in Nishimura 1968); Kitaura, Yamaguchi Pref. (Anon. 1965); Japan Sea coast of Yamaguchi Pref. (Kawamoto \& Tanabe 1956); Enmyôji coast near Ogura, northwest Kyushu (Wakita 1967); Hakata Bay (Ohshima 1930); Fukuoka (Takahashi \& OKamoto 1948); Shingû-hama near Fukuoka (Tabeta \& Tsukahara 1967); Ulchin, east Korea (Kamita 1938).

For the occurrence pattern and some biological peculiarities of this species in the Japan Sea, see Nishimura (1968).

Argonauta hians Solander, 1786

J.n.: Takobuné

Aomori Bay (Sasaki 1929a); Oga Peninsula (Nishimura \& Watanabe 1943); Nezugaseki, Yamagata Pref. (Suzuki 1963); Toyama Bay (Ichrjma 1927); Tsuruga (Kuroda 1933); Fukui Pref. (Furukawa \& Kubota 1947); Tajima Prov. [Hyôgo Pref.] (Yagura 1932; Ito 1967); Japan Sea coast of Yamaguchi Pref. (Kawamoto \& Tanabe 1956).

Argonauta boettgeri Maltz.AN, 1881 J.n.: Chijimi-takobuné

Niyû, Fukui Pref. (Kuroda 1933); Fukui Pref. (Furukawa \& Kubota 1947);

2) “崫諧俗談”

3) “耽奇漫録” 
Kuriya, Fukui Pref. (Kubota 1962); Tajima Prov. [Hyôgo Pref.] (Yagura 1932; Iто 1967).

\section{APPENDIX}

Empty shells of Nautilus pompilius LinNaeus, 1758 (J.n.: Ômugai) are rarely picked up on the coasts of the Japan Sea; published records include the following localities: Fukuura, Noto Peninsula (Anon. 1889); Chichii, Oki Islands (Kamrta 1962, 1965); Mita Bay, Oki Islands (Kamita 1965).

Of course, these records are the results of the post-mortem drift $\cdot$ of shells by ocean currents from the Recent habitat of Nautilus (Hamada 1965).

\section{Faunistic Notes}

As described above, the pelagic cephalopod fauna of the Japan Sea consists of 14 (or 18) species of Decembrachiata and 7 species of Octopodida. Of these, the following five species are definitely autogenetic in this marginal sea:

Enoploteuthis chunii, E. theragrae, Watasenia scintillans, Gonatus magister, Todarodes pacificus

On the other hand, the following species are considered allogenetic, namely, they are migrants from the waters outside the Japan Sea and unable to reproduce within that sea under the normal condition:

Regular migrants-Ommastrephes bartrami, Thysanoteuthis rhombus, Tremoctopus violaceus, Ocythoe tuberculata, Argonauta argo

Occasional migrants-Architeuthis sp., Cranchia scabra, Crystalloteuthis behringiana, Amphitretus pelagicus, Argonauta hians, A. boettgeri

It is difficult at preseat to judge whether the following five species are autogenetic or allogenetic:

Abralia japonica, Gonatus fabricii, Gonatopsis borealis, Onychoteuthis banksi, Alloposus mollis

Of the autogenetic species, Todarodes pacificus is flourishing in the epi- to mesopelagic layers, all of the three enoploteuthids are predominant in the mesopelagic layer, and Gonatus magister is prevailing in the bathypelagic layer. All of these squids are very abundant in respective layers and play each an extremely important role in the bio-economy of the Japan Sea, either as a voracious predator upon smaller animals on one hand or as a ubiquitous prey for larger carnivores on the other hand.

It is interesting that the species listed above as regular migrants are all epipelagic animals living in the tropical and subtropical seas and transported into the Japan Sea by strong warm ocean currents. Architeuthis sp., Cranchia scabra and Amphitretus pelagicus, which are likewise tropical-subtropical species but live at deeper levels, are apparently rarer in the Japan Sea. Other warm-water meso- to bathypelagic cephalopods, Taonius pavo (Lesueur) and Opisthoteuthis depressa IJIMA \& IKEDA for instance, 
can also be expected to penetrate into this marginal sea, though they are still undiscovered.

\section{REFERENCES}

Akimushrin, I. I. 1963. [The Cephalopoda of the seas of the U.S.S.R.] Izd. Akad. Nauk SSSR, Moskva \& Leningrad, 236 pp. (In Russian).

Anonymous 1889. [Nautilus shell from Noto]. Chigaku Zasshi, vol. 1 (In Japanese).

Anonymous 1956. [Peculiar animals and plants of Yamaguchi Prefecture]. Yamaguchi Pref. Office, Education. Sect., Yamaguchi. (In Japanese).

Berry, S. S. 1911. Note on a new Abraliopsis from Japan (A. scintillans n. sp.) Nautilus, vol. 25, pp. 93-94.

1912. A catalogue of Japanese cephalopods. Proc. Acad. Nat. Sci. Philadelphia, 1912, pp. 380-444, pls. V-IX.

Furukawa, D. \& Kubota, H. 1947. A catalogue of molluscan shells from Fukui Prefecture. ii +49 pp., 1 map. (In Japanese).

Hamabe, M. 1957. [A giant squid collected at Kuniga, Oki Islands]. Nihonkai Suisan Shiken Kenkyu Renraku Nyûsu, no. 82, p. 3. (In Japanese).

1962. Embryological studies of the common squid, Ommastrephes sloani pacificus STEENsTrup, in the southwestern waters of the Sea of Japan. Bull. Japan Sea Reg. Fish. Res. Lab., no. 10, pp. 1-45. (In Japanese).

1965. [Studies on the embryology and ecology of the common squid, Ommastrephes sloani pacificus Strenstrup, in the Japan Sea]. Private circulation, 189 pp. (In Japanese).

Hamada, T. 1965. Post-mortem drift of Nautilus. The Venus, Japan. J. Malacol., vol. 24, pp. 181198, pl. 20. (In Japanese).

Наsнimoto, T. 1965. [Correspondence to the editor]. Chiribotan, Tokyo, vol. 3, p. 142. (In Japanese).

Hirase, Y. 1907. [Catalogue of marine shells of Japan to be had of Y. Hirase]. Kyoto, 49 pp., 3 pls. (In Japanese).

IchijıMA, U. 1927. [A list of aquatic animals and plants of Toyama Prefecture, pt. I]. Namerikawa, Toyama Pref., ii+16 pp. (In Japanese).

IKEHARA, K. 1965. [Argonauta argo caught in Ryôtsu Bay]. Nihonkai Suisan Shiken Kenkyu Renraku Nyûsu, no. 165, p. 2. (In Japanese).

Ishikawa, C. 1913a. Note on the hectocotylised arm of the Pacific form of Ommastrephes, O. sloani sloani GRAY. Zool. Anz., Bd. 42, pp. 586-589.

- 1913b. Einige Bemerkungen über den leuchtenden Tintenfisch, Watasea nov. gen. (Abraliopsis der Autoren) scintillans BerRy, aus Japan. Ibid., Bd. 43, pp. 162-172.

1914. Ueber eine neue Art von Enoploteuthis, Enoploteuthis chunii spec. nov., aus Uwodu, Japanisches Meer. J. Coll. Agr., Imp. Univ. Tokyo, vol. 3, pp. 401-413.

\& WAKIYA, Y. 1914. Note on a gigantic squid obtained from the stomach of a sperm whale. Ibid., vol. 4, pp. 435-443.

Ishikawa, M. 1929. On a new species of a luminous squid from the Sea of Japan. Proc. Imp. Acad. Japan, vol. 5, pp. 51-54.

- 1933. [Cephalopoda]. In Yûyô Yûgai Kanshô Suisan Dôshokubutsu Zusetsu, pp. 352360. (In Japanese).

Ishikawa Pref. Fish. Exp. Stat. 1958. [Data report for the cooperative pelagic and bottom fish resources investigation conference in 1958]. Usetsu, Mimeogr. (In Japanese).

ITo, K. 1967. A catalogue of the marine molluscan shell-fish collected on the coast of and off Tajima, Hyogo Prefecture. Bull. Japan Sea Reg. Fish. Res. Lab., no. 18, pp. 39-91. (In Japanese).

Ito, S., Okiyama, M. \& Kasahara, Sh. 1965. Some consideration on the common squid, Todarodes pacificus Steenstrup, in the off-shore region of the Japan Sea. Ibid., no. 15, pp. 55-70. (InJapanese). 
Iwasawa, H. 1962. Marine invertebrates of Kanaizumi coast, Sado Island. Sado Hakubutsukan Kampô, no. 9, pp. 7-13. (In Japanese).

Joubin, L. 1897. Observations sur divers Céphalopodes. Troisième note: Céphalopodes du Musée Polytechnique de Moscou. Bull. Soc. Zool. France, tome 22, pp. 96-104.

Kamita, T. 1938. [Two additions to the cephalopod fauna of Korea]. Dôbutsugaku Zasshi, vol. 50, pp. 472-473. (In Japanese).

1962. Visits by unusual aquatic animals to the sea coasts of San-in District, Japan Sea. San-in Bunka Kenkyu Kiyô, no. 2, pp. 1-35. (In Japanese).

nese).

Kawamoto, T. \& Tanabe, S. 1956. Catalogue of molluscan shells of Yamaguti Prefecture. Yamaguti, iv $+x+171$ pp., 1 pl. (In Japanese).

Kikuchi, K. 1931. [Catalogue of the Mollusca of Toyama Bay]. Toyama, 40 pp. (In Japanese).

Kinoshita, T. 1939. [Three strange animals on the beach near Yoichi]. Hokusuishi Jumpô, no. 444, pp. 227-228. (In Japanese).

Kobayashi, T. 1954. Izumonauta, a new genus of the Argonautinae, with a note on their rare but gregarious fossil occurrence. Japan. J. Geol. \& Geogr., vol. 25, pp. 21-34, pls. 3-4.

Kondakov, N. N. 1941. [Cephalopods of the Far-Eastern seas of the U.S.S.R.] Issled. Dalnevost. Morei SSSR, vyp. 1, pp. 216-255. (In Russian).

Kubota, H. 1962. A catalogue of the molluscan shell specimens in the Fukui Municipal Museum (Natural History). Fukui, v $+242 \mathrm{pp}$. (In Japanese).

Kuroda, T. 1933. [A catalogue of the molluscan shells of Fukui Prefecture]. Fukui-ken Seibutsu Mokuroku, Fukui, pp. 169-205. (In Japanese).

Matsuno, S. 1914. [Luminous squids and cuttlefish of Toyama Bay]. Suisan Kenkyu Shi, vol. 9, pp. 317-320. (In Japanese).

1921. [Studies on Hotaruika, Watasenia scintillans (BERRY), pt. 1]. Toyama Suikô Hôkoku, Namerikawa. (In Japanese).

Mizusawa, R. 1964. [Occurrence of Cranchia scabra Leach]. Saishu to Shiiku, vol. 26, p. 334. (In Japanese).

- 1967. Alloposus mollis Verrill. Ibid., vol. 29, p. 396. (In Japanese).

Nakamura, M. 1925. [Natural products of Niigata Prefecture]. Niigata, xi +704 pp., 3 pls. (In Japanese).

Nishimura, M. \& Watanabe, K. 1943. [A catalogue of molluscan shells of Oga Peninsula]. Shigen Kagaku Kenkyusho Ihô, no. 3, pp. 63-74. (In Japanese).

Nishimura, S. 1960a. Occurrence of the giant flying squid, Thysanoteuthis rhombus Trosches, around Sado Island...... Saishu to Shiiku, vol. 22, pp. 168-170. (In Japanese).

1960b. Visits by unusual aquatic animals to the sea coasts of Niigata Prefecture, Japan Sea, in the winter of 1959-60. Ibid., vol. 22, 213-216. (In Japanese).

1961. Occurrence of a pelagic octopod, Tremoctopus violaceus Delle ChIAJE, off the coasts of Niigata Prefecture in the Japan Sea. Ibid., vol. 23, pp. 322-323. (In Japanese).

1962. [An outbreak of the paper nautilus]. Nihonkai Suisan Shiken Kenkyu Renraku Nyûsu, no. 132, p. 2. (In Japanese).

1964. Additional information on the biology of the dealfish, Trachipterus ishikawai JoRdan \& Snyder. Bull. Japan Sea Reg. Fish. Res. Lab., no. 13, pp. 127-129.

1966. Notes on the occurrence and biology of the oceanic squid, Thysanoteuthis rhombus Troscher, in Japan. Publ. Seto Mar. Biol. Lab., vol. 14, pp. 327-349.

1968. Glimpse of the biology of Argonauta argo Linnaeus (Cephalopoda: Octopodida) in the Japanese waters. Ibid., vol. 16, pp. 61-70.

Okiyama, M. 1965. Some considerations on the eggs and larvae of the common squid Todarodes pacificus Steenstrup. Bull. Japan Sea Reg. Fish. Res. Lab., no. 15, pp. 39-53. (In Japanese). 
Oırsima, H. 1930. [Amakusa miscellanies, pt. 3]. Dôbutsugaku Zasshi, vol. 42, pp. 29-37. (In Japanese).

SAMON, T. 1964. [On the migration and fishing condition of Thysanoteuthis rhombus off the coast of Echizen District]. Nihonkai Suisan Shiken Kenkyu Renraku Nyûsu, no. 163, p. 2. (In Japanese).

Sasaki, M. 1914. Observations on Hotaru-ika Watasenia scintillans. J. Coll. Agr., Tohoku Imp. Univ., Sapporo, vol. 6, pp. 75-107, pls. I-III.

1916. Notes on oegopsid cephalopods found in Japan. Annot. Zool. Japon., vol. 9, pp. 89-120, pl. III.

1920. Report on cephalopods collected during 1906 by the United States Bureau of Fisheries steamer "Albatross" in the northwestern Pacific. Proc. U. S. Natl. Mus., vol. 57, pp. 163-203, pls. 23-26.

1921. On the life history of an economic cuttlefish of Japan, Ommastrephes sloani pacificus.

Trans. Wagner Free Inst. Sci. Philad., vol. 9, pt. 2, pp. 1-25.

1929a. A monograph of the dibranchiate cephalopods of the Japanese and adjacent

waters. J. Fac. Agr., Hokkaido Imp. Univ., vol. 20, suppl. no., pp. 1-357, pls. I-XXX.

1929b. Supplementary notes on the life history of an economic cuttlefish, Ommasirephes sloani pacificus SteenstruP. Japan. J. Zool., vol. 2, pp. 199-211.

Shimomura, T. \& Fukataki, H. 1957. On the year round occurrence and ecology of eggs and larvae of the principal fishes in the Japan Sea-I. Bull. Japan Sea Reg. Fish. Res. Lab., no.6, pp. 155290.

Slepzov, M. M. 1955. On the biology of cephalopod molluscs of the Far-Eastern seas and the northwestern Pacific. Tr. Inst. Okeanol., Akad. Nauk SSSR, tom 18, pp. 69-77. (In Russian).

Steenstrup, J. 1880. Orientering i de Ommastrephagtige blaecksprutters indbyrdes Forhold. Overs. Danske Vid. Selsk. Forh., 1880, pp. 73-110.

Suzuki, SH. 1963. Fauna of the coast and the adjacent sea of Shônai I. Invertebrata. Yamagata, ii +43 pp. (In Japanese).

TABATA, K. 1958. [Exploitation of new fishing grounds by means of D.S.L.] Tsushima-Danryû Kaihatsu Chôsa Hôkokusho, ser. III, pp. 259-262. (In Japanese).

Tabeta, O. \& Tsukahara, H. 1967. Ecological studies on the fishes stranded upon the beach along the coast of the Tsushima current-I. Fishes and other animals recorded during the first half of 1965 in northern Kyushu. Bull. Japan. Soc. Sci. Fish., vol. 33, pp. 295-302.

Takahashi, G. \& Окамото, M. 1948. [A catalogue of molluscan shells from Fukuoka Prefccture]. Fukuoka. (In Japanese).

TAKI, Iw. 1964. On eleven new species of the Cephalopoda from Japan, including two new genera of Octopodidae. J. Fac. Fish. \& Animal Husband, Hiroshima Univ., vol. 5, pp. 277-343, 7 pls.

1965. [Class Cephalopoda]. In UchidA, T. et al. (ed.), New Illustrated Encyclopedia of the Fauna of Japan, pt. II, pp. 307-326. (In Japanese).

\& Igarashi, K. 1967. A list of cephalopod specimens in the Fisheries Museum, Faculty of Fisheries, Hokkaido University. Fish. Mus., Fac. Fish., Hokkaido Univ., Contrib. no. 7, 27 pp. (In Japanese).

Tanabe, M. \& Ukawa, M. 1958. [On the hydrography and fisheries conditions off Aomori Prefecturc]. Tsushima-Danryû Kaihatsu Chôsa Hôkokusho, ser. I, pp. 427-454. (In Japanese).

Tanaka, I. 1950. [Glory of rare fishes]. Hagi Bunka Sôsho, no. 2. (In Japanese).

TANAKA, O. \& IrzukA, S. 1956. On a Japanese squid "Surume-ika" Ommastrephes sloani pacificus (Steenstrup) in the north-western waters of Kyûsyû. Bull. Fac. Fish., Nagasaki Univ., no. 4, pp. 31-40. (In Japanese).

ToвA, G. 1935. [Talks about the molluscan shells of Tôhoku, pt. 6]. The Venus, Japan. J. Malacol., vol. 5, pp. 117-120. (In Japanese).

Tokuhisa, M. 1915. [Fishes, cephalopods and molluscan shells of Ishikawa Prefecture]. Suisan Kenkyu Shi, vol. 10, pp. 119-132. (In Japanese).

Toyama Pref. Fish. Exp. Stat. 1965. [Data report for the Japan Sea Fisheries Conference in 1964]. Namerikawa, Toyama Pref., Mimeogr. (In Japanese). 
Tsutsur, Y., Yамamoto, S. \& Ogawa, Y. 1963. [Fauna and its conservation in the San'in Coastal National Park]. San'in Kaigan Kokuritsu Kôen Kôhochi Gakujutsu Chôsa Hôkokusho, pp. 77-87. (In Japanese).

Ueno, T. 1964. [Strange octopods captured at Furubira and Yoichi]. Hokusuishi Geppô, vol. 21, pp. 427-428. (In Japanese).

Wakita, O. 1967. [Correspondence to the editor]. Fukui-shi Kyôdo Hakubutsukan Dayori, no. 125, p. 1. (In Japanese).

Watanabe, T. et al. 1958. A study on the structure of bottom fish communities at trawling ground, off Port Tsuiyama in Hyogo Prefecture. Bull. Fish. Exp. Stat. Hyogo-ken, no. 9, pp. 1-20, 3 tables. (In Japanese).

Watasé, S. 1905. [Luminous organs of Hotaru-ika]. Dôbutsugaku Zasshi, vol. 17, pp. 119-123. (In Japanese).

WülkeR, G. 1910. Ueber japanische Cephalopoden. Beiträge zur Kenntnis der Systematik und Anatomie der Dibranchiaten (F. Doflein, Beiträge zur Naturgeschichte Ostasiens). Abh. Math.Phys. Kl. K. Bayer. Akad. Wiss., IIl. Suppl.-Bd. 1. Abh., 71 pp., 5 pls.

YAGURA, W. 1932. [Catalogue of molluscan shells of Hyôgo Prefecture, with appendix of that of Molluscoidea (revised ed.)]. Nishinomiya, Kôbe, iv +63+viii pp., 5 ( 1 col.) pls. (In Japanese).

YAMADA, T. 1937. On the spawning of the squid, Watasenia scintillans, in the waters of the east coast of Tyôsen. Bull. Japan. Soc. Sci. Fish., vol. 6, pp. 75-78. (In Japanese).

YamAGUCHI, E. \& YAMADA, M. 1955. [Marine invertebrates of northern Japan]. Sapporo, iv +189 pp. (In Japanese).

Yамамото, T. 1942. On the distribution of cephalopods in Korea. The Venus, Japan. J. Malacol., vol. 11, pp. 126-133. (In Japanese).

1946. [On the eggs and larvae of the common squid, Ommasirephes sloani pacificus (STEENSTRUP) collected from the Korean waters]. Ibid., vol. 14, pp. 228-240. (In Japanese).

1951. [On several hitherto unrecorded animals from off Tajima Province]. Hyôgo Seibutsu, Kôbe, vol. 1, pp. 74, 84-85. (In Japanese). 